\title{
PENINGKATAN KEMAMPUAN BACA PADA SISWA KELAS 2 SD NEGERI 6 KLABLIM KOTA SORONG MELALUI MEDIA KARTU HURUF
}

\author{
Yulita Kambu
}

\author{
PGSD STKIP Muhammadiyah Sorong
}

\begin{abstract}
ABSTRAK
Tujuan penelitian tindakan kelas ini adalah untuk meningkatkan prosespembelajaran kemampuan membaca lancar pada siswa kelas 2Kelas 2 SD Negeri 6 Klablim Kota Sorong Distrik Sorong Timur tahun pelajaran 2015/2016. Penelitian ini didesain dua siklus, dalam setiap siklus terdiri dari dua pertemuan. Setiap siklus mencakup tahapan diantaranya: perencanaan, pelaksanaan, observasi, dan refleksi. Subjek penelitian seluruh siswa kelas 2 yakni 34 siswa. Teknik pengumpulan data menggunakan dokumentasi, observasi, dan wawancara, sedangkan analisis data yang digunakan adalah model analisis kualitatif. Berdasarkan hasil penelitian tindakan kelas yang dilakukan sebagai berikut: 1). Melalui penggunaaan media kartu huruf dapat meningkatkan ketrampilan membaca siswa yang dapat dilihat dengan adanya peningkatan pada prosentase siswa yang tuntas yakni pratindakan sebesar $56 \%$ siklus pertama pertemuan 1 sebesar $70 \%$ naik pada siklus pertama pertemuan 2 sebesar $88 \%$, siklus kedua pertemuan 1 sebesar $100 \%$ dan siklus ke dua pertemuan 2 sebesar 100\%. 2). Melalui penggunaan media kartu huruf dapat meningkatkan keaktifan dan kekreatifan siswa pada scat pelaksanaan pembelajaran bahasa Indonesia, khususnya dalam pembelajaran membaca.
\end{abstract}

Kata kunci: Kemampuan Baca, Media Kartu Huruf

\section{ABSTRACT}

The research objective of this class action is to improve learning ability to read fluently in Class 2 Class 2 SD Negeri 6 Klablim Sorong City of District Sorong East in the academic year 2015/2016. This study was designed two cycles, in each cycle includes the stages include: action planning, action, observation, and reflection. The method in this research is the Classroom Action Research (PTK) with the model cycle and the study was conducted in two cycles, each cycle consists of two meetings, then the subject is taken from all students in grade 2 with the number of 34 students. At each cycle is measured from the observation and tests the ability to read. Data from observations described, interpreted, and then reflected to make improvements in the next cycle. While the test data between cycles until the result may be expected to be completed in accordance with performance indicators, ie at least $75 \%$ of students can follow the lesson well and scored 70 or more as limits of complete ability to read fluently.Based on the results of a classroom action research was conducted in two cycles through the use of media card letters in Class 2 SD Negeri 6 Klablim town of Sorong in Indonesian lesson about learning to read fluently can be concluded as follows: 1). Through the use of media cards letters can improve reading skills of students who can be seen with an increase in the percentage of students who pass the pratindakan by $56 \%$ the first cycle 1 meeting a $70 \%$ rise in the first cycle of meeting 2 by $88 \%$, the second cycle of meetings $1100 \%$ and cycle to two meetings two at 100\%. 2). Through the use of letter card media can enhance the activity and creativity of students in the Indonesian scat learning implementation, particularly in learning to read.

Keywords: read,card, media, letter. 


\section{PENDAHULUAN}

Wajib belajar 9 tahun, merupakan tujuan pemerintah dalam rangkamencerdaskan kehidupan bangsa serta memberikan bekal dasar bagi peserta didikterutama pada Sekolah tingkat dasar baik itu menulis, menghitung, dan membaca.Dilihat dari kenyataanya, belum terlihat adanya suatu perubahan yang berarti dalamsuatu Pendidikan dasar.

Banyak peneliti menyimpulkan bahwa kemampuan membaca anak-anakSekolah Dasar di Indonesia masih sangat rendah. Hasil penelitian internasional, Programme for International Student Assessment (PISA) tahun 2015 tentang kemampuan membaca siswa juga menyebutkan bahwa kemampuan membaca siswa di Indonesia menduduki urutan ke-69 dari 76 negara yang disurvei. Hasil itu lebih rendah dari Vietnam yang menduduki urutan ke-12 dari total negara yang disurvei (harian jogja.com, 2016).

Begitu juga dari hasil survei peneliti di Kelas 2 SD Negeri 6 Klablim Kota Sorong Distrik Sorong Timur,banyak siswa yang memiliki permasalahan terutama dalam hal membaca khususnyapada kelas rendah. Hal inilah yang di jadikan peneliti sebagai alasan mengapa penelitimengangkat permasalahan ini.

Adapun manfaat dan tujuan membaca adalah untuk memperoleh informasiserta menambah wawasan kita di dalam kehidupan. Serta tujuan membaca itu sendiriadalah: (1) Menemukan atau mengetahui penemuan yang dilakukan oleh sang tokoh;(2) Mengetahui mengapa hal itu merupakan topic yang baik dan menarik; (3) Untukmenemukan atau mengetahui apa yang terjadi pada setiap bagian cerita; (4) Untukmenemukan atau mengetahui mengapa para tokoh merasakan seperti cara mereka itu;(5) Untuk mengetahui apa yang tidak biasa mengenai seorang tokoh; (6) Untukmenemukan apakah sang tokoh berhasil atau hidup dengan ukuran-ukuran tertentu;(7) Untuk menemukan bagaimana cara sang tokoh berubah atau ada perbedaan darikita.Jika di kalangan siswa Sekolah Dasar tradisi membaca masih memprihatinkandikarenakan tidak bisa membaca atau lamban akan membaca, jelas diperlukan strategitersendiri untuk meningkatkanya. Tanpa upaya yang serius, siswa setiap saat bergelutdengan aktifitas menulis dan membaca, bisa juga akan lebih parah lagi. Oleh karenaitu sadar atau tidak sadar, aktifitas membaca memang memerlukan pembelajaranmembaca mulai usia sejak dini paling tidak mulai Taman Kanak-kanak.

Masalah tersebut masih menjadi impian terlalu jauh. Banyak hal yangmenyebabkan masyarakat Indonesia terutama pada anak sekolah dasar yang kurangmampu akan dapat membaca diantaranya adalah: (1) Kurangnya fasilitas bacaansecara lengkap; (2) Kurang terampilnya pengajar dalam mengajarkan membaca; (3)Sistem pendidikan kita, terutama system pendidikan formal yang belum memberikanpeluang cukup besar bagi hadirnya keberaksaraan bagi peserta didik; (4) Kurangpemahaman dan penguasaan materi, para pengajar baik pada hakikat, konsep,maupun teknik pembelajaran membaca.

Menurut Harjasujana (2001: 6) menyatakan bahwa tradisi keberaksaraanmasyarakat jenjang pendidikan rendah masih sangat memprihatinkan. Lebih lanjut dikatakan bahwa masyarakat professional sesungguhnya dituntut untuk berbudayabaca.

Salah satu masalah yang dihadapi dunia pendidikan dasar adalah rendahnya minat baca anak, tidak terkecuali di Kabupaten Sorong dan Kota Sorong, Papua Barat. Kabupaten Sorong memiliki penduduk sebanyak 78.698 Jiwa, dengan populasi jumlah anak usia sekolah ( $5-12$ Tahun ) adalah 16.816 jiwa atau sekitar $21 \%$. Besarnya jumlah usia anak sekolah, menunjukkan bahwa Kabupaten Sorong memiliki potensi sumber daya manusia yang besar, jika dibarengi dengan peningkatan mutu pendidikannya.

Faktanya, minat baca anak usia sekolah di Kabupaten Sorong dan Kota 
Sorong tergolong rendah. Berdasarkan penyataan Kepala perpustakaan umum kabupaten Sorong, Jumlah pengunjung yang datang hanya berkisar antara $3-10$ orang perhari bahkan terkadang tidak ada sama sekali, itu pun pengunjung dewasa. Di sisi lain, fasilitas membaca disekolah-sekolah masih terbatas, jika pun ada hanya menyediakan buku-buku kurikulum mata pelajaran, sehingga anak kurang tertarik untuk mengunjungi perpustakaan sekolah. Keluarga juga kurang berperan dalam menumbuhkan minat baca anak, karena latar belakang ekonomi dan pendidikan orang tua, sehingga disamping daya beli terhadap buku kurang, buku bacaan juga bukan menjadi prioritas kebutuhan. Akibatnya, akses anak terhadap keragaman ilmu pengetahuan dari buku-buku bacaan menjadi terbatas, sehingga dapat menghambat perkembangan kognitif anak.

Permasalahan ini bukan saja terjadi di Kabupaten Sorong, tetapi juga terjadi di Kota Sorong. SD Negeri 6 Klablim Kota Sorong Distrik Sorong Timur yang berada di Kota Sorong juga tidak lepas dari permasalahn tersebut. Siswa-siawa SD Negeri 6 Klablim Kota Sorong Distrik Sorong Timur masih banyak tidak bias membaca, bahkan tidak mengenal huruf.

Berdasarkan permasalahan di atas maka peneliti mengambil judul peningkatankemampuan membaca lancar dengan media kartu huruf dalam pembelajaran BahasaIndonesia pada siswa kelas 2Kelas 2 SD Negeri 6 Klablim Kota Sorong Distrik Sorong Timurtahun ajaran 2015/2016. Penelitian ini bertujuan untuk menjawab permasalahan di atas yaitu:meningkatkan kemampuan membaca pada anak Kelas 2 SD Negeri 6 Klablim Kota Sorong Distrik Sorong Timur.

\section{METODE PENELITIAN}

Dalam penelitian ini, peneliti menggunakan model penelitian yaitu Penelitian Tindakan Kelas (PTK) sebagaimana yang dikemukakan oleh Hopkins (dalam, Arikunto 2001:105) yang secara garis besar dibagi dalam 4 tahapan yang dilalui yaitu perencanaan, pelaksanaan, observasi, refleksi.

\subsection{PROSEDUR \\ PELAKSANAAN PENELITIAN}

Prosedur penelitian tindakan merupakan gambaran secara lengkap mengenailangkah-langkah yang akan dilakukan dalam penelitian. Tindakan yang ditempuhdimaksudkan untuk mengubah kondisi atau perilaku yang mencakup rencana,tindakan, observasi dan refleksi. Prosedur rencana tindakan dalam penelitian inimempunyai target pencapaian indicator dari setiap siklusnya, dalam siklus pertamatarget pencapaian indikator adalah: (1) siswa mampu membaca dengan tidakmengulang-ulang kata; (2) siswa tidak gagap dalam membaca; (3) siswa mampumelavalkan kata dengan jelas; (4) siswa mampu menggunakan tanda baca denganbaik. Kemudian dalam siklus kedua target pencapaian indikatornya adalah: (1) siswamampu membaca dengan tidak mengulang-ulang kata; (2) siswa tidak gagap dalammembaca; (3) siswa mampu melavalkan kata dengan jelas; (4) siswa mampumenggunakan tanda baca dengan baik; (5) mampu mengucapkan kata dalam kalimat dengan intonasi(tinggi rendahnya suara, keras dan lemahnya suara)dengan tepat; (6)mampu mengendalikan emosional dalam membaca, dan rencana kegiatan tersebut adalah sebagai berikut : 1). Siklus I (yakni terdiri Rencana Tindakan, Rencana Pelaksanaan Tindakan I., Observasi, Refleksi), 2). Siklus II (yakni terdiri Rencana Tindakan, Rencana Pelaksanaan Tindakan I., Observasi, Refleksi)

\subsection{TEMPAT DAN WAKTU PENELITIAN}

\subsubsection{Tempat Penelitian}

Penelitian ini dilaksanakan di SD Negeri 6 Klablim Kota Sorong Distrik Sorong Timur. Waktu penelitian dilaksanakan pada semester II tahun pelajaran 2015/2016 dimulai bulan Mei sampai dengan Juni 2016.

\subsection{POPULASI DAN SAMPEL}

Populasi dalam penelitian ini adalah seluruh siswa diSD Negeri 6 Klablim Kota 
Sorong Distrik Sorong Timur. Dalam penelitian ini, Peneliti tidak menggunakan teknik sampling akan tetapimengambil subjek seluruh siswa kelas IISD Negeri 6 Klablim Kota Sorong Distrik Sorong Timursebanyak 34 peserta didik.

\subsection{IDENTIFIKASI DAN DEFINISI VARIABLE}

Variabel independent/bebas dalam penelitian ini adalah pemanfaatan Media Kartu HurufPada Siswa Kelas 2 SD Negeri 6 Klablim Kota Sorong Distrik Sorong Timur.

Variabel dependent/terikat dalam penelitian ini adalah Kemampuan Baca Pada Siswa Kelas 2 SD Negeri 6 Klablim Kota Sorong Distrik Sorong Timur.

\subsection{ALAT ATAU INSTRUMEN PENGAMBILAN DATA}

Dalam instrument penelitian, peneliti menggunakan tes formatif untuk mengetahui hasil belajar yang diperoleh siswa, menggunakan lembar observasi untuk mengetahui keaktifan siswa dalam proses pembelajaran. Pada tes formatif, siswa yang mendapatkan nilai yaitu > 60 dinyatakan tuntas dalam pembelajaran sedangkan yang mendapat nilai $<59$ dinyatakan tidak tuntas dalam pembelajaran.

\subsection{TEKNIK PENGUMPULAN DATA 1.6.1 Dokumentasi}

Teknik ini digunakan untuk mengumpulkan data yang berupa data-data tertulis,yaitu hasil ulangan harian. Kegiatan ini selain untuk mencatat semua dokumen dan arsip, juga untuk mendapatkan gambaran secara lengkap tentang dokumen tersebut.

\subsubsection{Observasi}

Observasi dilakukan observer terhadap guru kelas 1 dan siswakelas 2SD Negeri 6 Klablim Kota Sorong Distrik Sorong Timur untukmengetahui situasi dan perkembangan dalam proses belajar mengajar matapelajaran Bahasa Indonesia dengan media pembelajaran kartu huruf.

\subsection{TEKNIK ANALISIS DATA}

Langkah-langkah analisis:
1. Melakukan analisis awal bila data yang didapat di kelas sudah cukup, maka dapatdikumpulkan.

3. Mengembangkan dalam bentuk sajian data, dengan menyusun coding danmatrik yang berguna untuk penelitian lanjut.

4. Melakukan analisis data di kelas dan mengembangkan matrik antar kelas.

5. Melakukan verifikasi, pengayaan dan pendalaman data apabila dalampersiapan analisis ternyata ditemukan data yang kurang lengkap atau kurang jelas,maka perlu dilakukan pengumpulan data lagi secara terfokus.

6. Melakukan analisis antar kasus, dikembangkan struktur sajian datanya bagisusunan laporan.

7. Merumuskan simpulan akhir sebagai temuan penelitian.

8. Merumuskan implikasi kebijakan sebagai bagian dari pengembangan sarandalam laporan akhir penelitian.

\section{HASIL DAN PEMBAHASAN}

Hasil nilai tes kemampuan membaca lancar pada survei awal dapat dilihat pada tabel 4-1.

Tabel 0-1. Nilai Kemampuan Membaca Lancar Pratindakan

\begin{tabular}{cccc}
\hline Interv & Frekue & $\%$ & Ket. \\
\hline $50-$ & 15 & 44 & Tida \\
$60-69$ & 10 & 29 & Tunta \\
$70-79$ & 8 & 24 & Tunta \\
$80-89$ & 1 & 3 & Tunta \\
$90-100$ & 0 & 0 & \\
\hline
\end{tabular}

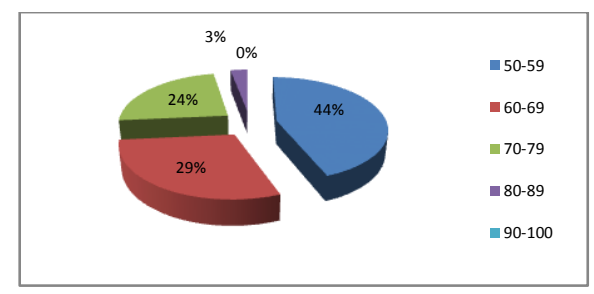

\section{Gambar 0-1. Grafik Persentase Nilai Kemampuan Membaca Lancar Pratindakan}

Dari tabel 4-1 diatas dapat di jelaskan bahwa siswa yang mendapat nilai antara 50-59 ada 15 anak, nilai 60-69 ada 10 anak, nilai 70 - 79 ada 8 anak, nilai $80-$ 89 ada 1 anak, dan nilai 90-100 tidak ada, sehingga dapat disimpulkan bahwa ada 9 
anak yang sudah tuntas yaitu $42,86 \%$ dan ada 15 anak yaitu $44 \%$ yang 'velum tuntas dalam mengikuti tes kemampuan membaca lancar. Nilai tertinggi yang diperoleh yaitu 83 sedangkan nilai terendah yaitu 58 , dengan nilai rata-rata kelas dari pratindakan ini adalah 69,95 agar lebih jelasnya dapat dilihat diagram 1 tes kemampuan membaca lancar pratindakan dibawah ini.

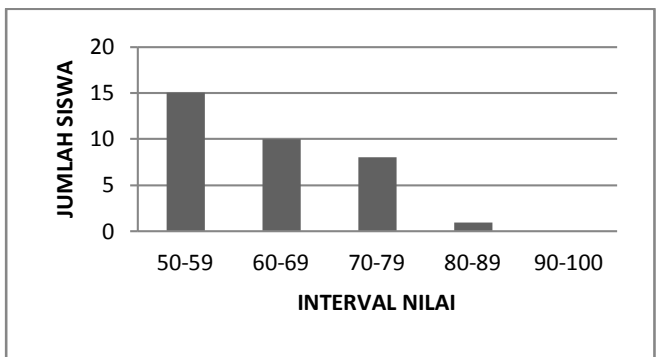

\section{Gambar 0-2. Grafik nilai membaca lancar pratindakan}

Deskripsi Tindakan Siklus I

Kegiatan evaluasi ini ssma dengan ketika siswa melakukan kegiatan inti yaitu merangkai kartu huruf menjadi kata kemudian merangkai kata menjadi kalimat, hanya saja evaluasi ini dilakukan secara individu dengan memperoleh nilai yang disajikan dalam label 4-2 di bawah ini:

Tabel 0-2. Nilai Kemampuan Membaca lancar Siklus I Pertemuan I

\begin{tabular}{cccc}
\hline Interval & frekue & $\mathbf{\%}$ & Ket. \\
\hline $50-59$ & 4 & 15 & Tdk \\
$60-69$ & 12 & 35 & Tdk \\
$70-79$ & 7 & 21 & Tuntas \\
$80-89$ & 8 & 23 & Tuntas \\
$90-100$ & 2 & 6 & Tuntas \\
\hline & $\mathbf{3 4}$ & $\mathbf{1 0}$ & \\
\hline
\end{tabular}

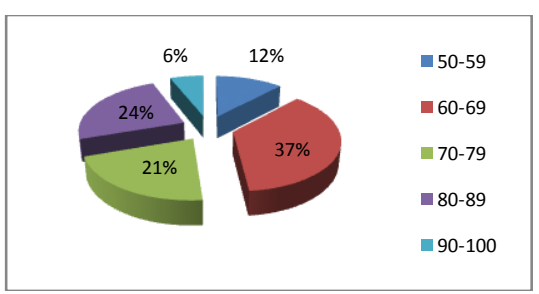

Gambar 0-3. Grafik Ketuntasan Siswa Pada Nilai Kemampuan Membaca lancar Siklus I Pertemuan 1.

Dari tabel 4-2 diatas dapat dijelaskan bahwa sisw,a yang, mendapat nilai antara 50-59 ada 4 anak, nilai 60-69 ada 12 anak, nilai 70 - 79 ada 7 anak, nilai $80-89$ ada 8 anak, dan nilai 90-100 ada 2 anak, sehingga dapat disimpulkan bahwa ada 16 anak yang sudah tuntas yaitu $70 \%$ dan ada 5 anak yaitu $30 \%$ yang belum tuntas dalam mengikuti tes kemampuan membaca lancar. Nilai tertinggi yang diperoleh yaitu 92 sedangkan nilat terendah yaitu 58, dengan nilai rata-rata Was dari pratindakan ini adalah 77, agar lebih jelasnya dapat dilihat diagram 2 tes kemampuan membaca lancar pratindakan dibawah ini.

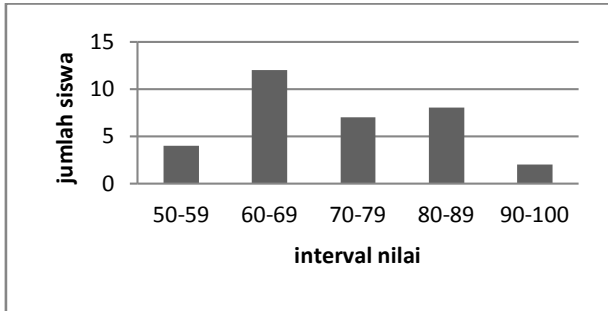

Gambar 0-4. Grafik nilai membaca lancar Siklus 1 Pertemuan 11

\section{5 '.7.1.1 Pertemuan 2}

Hasil nilai tes kernampuan nembaca lancar Siklus 1 pertemuan 2 dapat dilihat pada tabel 4-3 berikut ini.

Tabel 0-3. Nilai Tes Kemampuan Membaca lancar Siklus I Pertemuan 2

\begin{tabular}{cccc}
\hline Interval & frekue & $\%$ & Ket. \\
\hline $50-59$ & 0 & 0 & Tdk \\
$60-69$ & 4 & 12 & Tdk \\
$70-79$ & 10 & 29 & Tuntas \\
$80-89$ & 12 & 35 & Tuntas \\
$90-100$ & 8 & 24 & Tuntas \\
\hline & $\mathbf{3 4}$ & $\mathbf{1 0}$ & \\
\hline
\end{tabular}

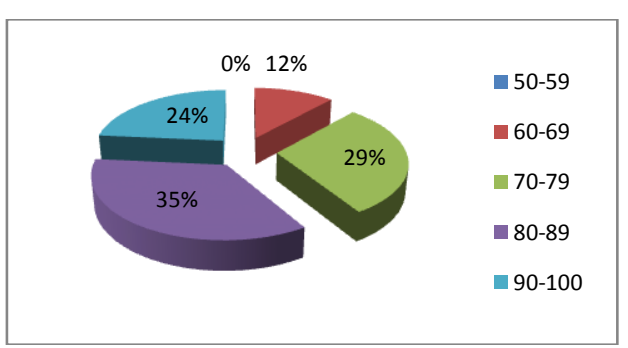

Gambar 0-5. Grafik Persentase Nilai Tes Kemampuan Membaca lancar Siklus I Pertemuan 2

Dari tabel 4-3 di atas dapat dijelaskan bahwa siswa yang mendapat nilai antara 50-59 tidak ada, nilai 60-69 ada 4 anak, nilai 70 - 79 ada 10 anak, nilai 8089 ada 12 anak, dan nilai $90-100$ ada 8 
anak, sehingga dapat disimpulkan bahwa ada 30 anak yang sudah tuntas yaitu $90,48 \%$ dan ada 4 anak yaitu $9,52 \%$ yang belum tuntas dalam mengikuti tes kemampuan membaca lancar. Nilai tertinggi yang diperoleh yaitu 92 sedangkan nilai terendah yaitu 67 , dengan nilai rata-rata kelas dari tindakan ini adaiah 81,67, agar lebih jelasnya dapat dilihat Gambar 4-7 tes kemampuan membaca dibawah ini.

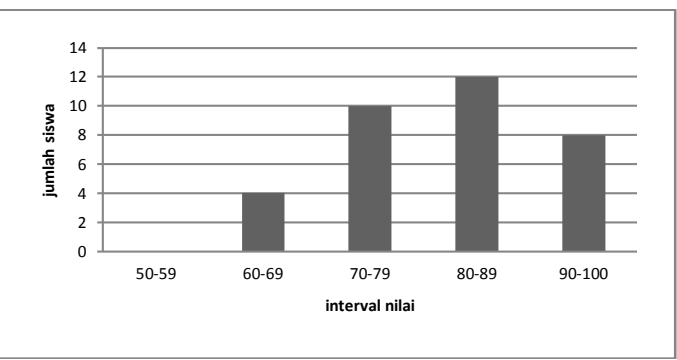

Gambar 0-6. Grafik nilai membaca lancar Siklus I Pertemuan

1.8 Hasil Penelitian Siklus II

Siklus 2 tindakan pertama I

Hasil pembelajaran membaca pada siklus 2 pertemuan 1 dapat dilihat pada Tabel 4-4.

Tabel 0-4. Nilai Tes Kenjampuan Mentbaca Siklus 2 Pertentuan 1

\begin{tabular}{cccc}
\hline Interval & Frekue & \% & Ket. \\
\hline $50-59$ & 0 & 0 & Tdk \\
$60-69$ & 2 & 6 & Tdk \\
$70-79$ & 8 & 24 & Tuntas \\
$80-89$ & 14 & 41 & Tuntas \\
$90-100$ & 10 & 29 & Tuntas \\
\hline & $\mathbf{3 4}$ & $\mathbf{1 0 0}$ & \\
\hline
\end{tabular}

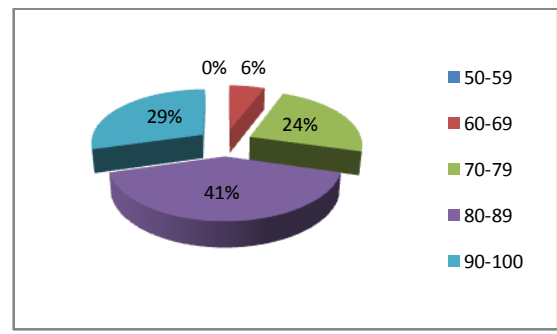

Gambar 0-7. Gralik Persentase Nilai Tes Kemampuan Membaca Siklus 2 Pertemuan 1

Dari tabel 4-4 di atas dapat dijelaskan bahwa siswa yang mendapat nilai antara 5059 tidak ada, nilai 60-69 ada 2 anak, nilai 70 - 79 ada 8 anak, nilai 80-89 ada 14 anak, dan nilai 90-100 ada 10 anak, sehingga dapat disimpulkan bahwa ada 30 anak yang sudah tuntas yaitu $94 \%$ dan ada 4 anak yaitu $6 \%$ yang belum tuntas dalam mengikuti tes kemampuan membaca lancar. Nilai tertinggi yang diperoleh yaitu 92 sedangkan nilai terendah yaitu 67 , dengan nilai rata-rata kelas dari tindakan ini adalah 81,67, agar lebih jelasnya dapat dilihat diagram tes kemampuan membaca pada gambar 4-8 dibawah ini.

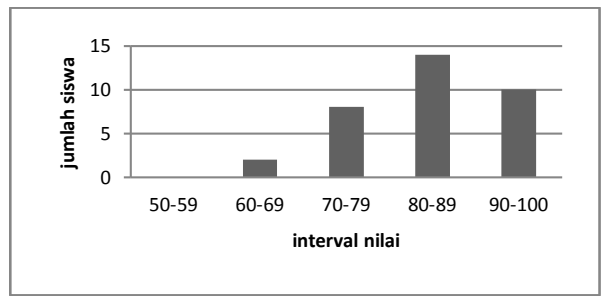

Gambar 0-8. Grafik nilai membaca siklis 2 pertemuan

\subsubsection{Siklus 2 tindakan pertama 2}

Evaluasi dilakukan secara individu yaitu tes membaca dengan tanda baca, lafal dan intonasi yang benar sesuai absen selama 20 menit. Hasil diperoleh seperti ditampilkan pada tabel 4-5.

Tabel 0-5. Nilai Tes Kernampuan Baca Siklus 2 Pertemuan 2

\begin{tabular}{cccc}
\hline Interval & Medi & $\%$ & Ket. \\
\hline $50-59$ & 0 & 0 & Tdk \\
$60-69$ & 0 & 0 & Tdk \\
$70-79$ & 7 & 21 & Tuntas \\
$80-89$ & 15 & 42 & Tuntas \\
$90-100$ & 12 & 35 & Tuntas \\
\hline & $\mathbf{3 4}$ & $\mathbf{1 0 0}$ & \\
\hline
\end{tabular}

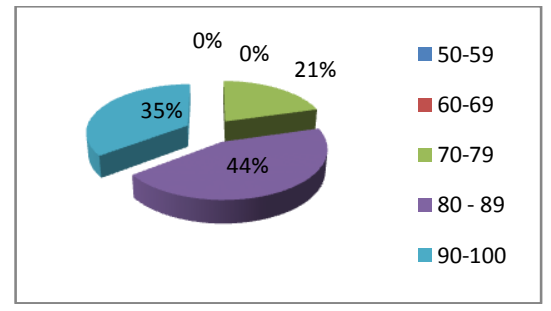

Gambar 0-9. Grafik Persentase Nilai Tes Kemampuan Baca Siklus 2

Pertemuan 2.

Dari tabel 4-5 di atas dapat dijelaskan bahwa siswa yang mendapat nilai antara 50-59 tidak ada, nilai 60-69 ada 2 anak, nilai $70-79$ ada 8 anak, nilai 80-89 ada 14 anak, dan nilai $90-100$ ada 10 anak, sehingga dapat disimpulkan bahwa 
ada 30 anak yang sudah tuntas yaitu 94\% dan ada 4 anak yaitu $6 \%$ yang belum tuntas dalam mengikuti tes kemampuan membaca lancar. Nilai tertinggi yang diperoleh yaitu 92 sedangkan nilai terendah yaitu 67, dengan nilai rata-rata kelas dari tindakan ini adalah 81,67, agar lebih jelasnya dapat dilihat diagram tes kemampuan membaca pada gambar 4-11 dibawah ini.

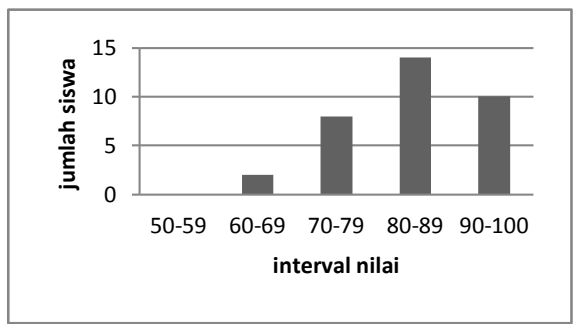

\section{Gambar 0-10. Grafik nilai membaca siklus 2 pertemuan 2}

Kemampuan membaca siswa kelas 2 SD Negeri 6 Klablim Kota Sorong tahun pelajaran 2015/2016 dapat meningkat dengan diterapkannya penggunaan media kartu huruf Peningkatan tersebut bukan hanya pada nilai akhir membaca saga tetapi juga pada keaktifan siswa dalam mengikuti pembelajaran meningkat dari siklus pertama ke siklus kedua. Hal ini dapat dilihat dari hasil pengamatan terhadap aktivitas siswa dalam proses pembelajaran. Selain keaktifan, terlihat pula terjadinya peningkatan pada aspek keberanian, kreatifitas dan inisiatif siswa. berikut ini digambarkan perbandingan kemampuan baca siswa yang ditampilkan pada tabel 4-6

Tabel 0-6. Perbandingan basil tindakan persiklus

\begin{tabular}{cccccc}
\hline & pratindak & \multicolumn{2}{c}{ Siklus 1 } & \multicolumn{2}{c}{ Siklus 2 } \\
\cline { 3 - 6 } I & an & Pertemuan & Pertemuan & Pertemuan & Pertemuan \\
\hline $50-59$ & 15 & 4 & 0 & 0 & 0 \\
$60-69$ & 10 & 6 & 4 & 2 & 0 \\
$70-79$ & 8 & 10 & 10 & 8 & 7 \\
$80-89$ & 1 & 10 & 12 & 14 & 15 \\
$90-$ & 0 & 4 & 8 & 10 & 12 \\
\hline
\end{tabular}

Lebih jelasnya dapat dilihat pada table 4-7 yang menunjukkan peningkatan kemampuar membaca dari pratindakan sampai siklus kedua dibawah ini.

Tabel 4.7 Perbandingan Prantindakan siklus

\begin{tabular}{cccccc}
\hline keterangan & prat & \multicolumn{2}{c}{ Siklus } & \multicolumn{3}{c}{ Siklus 2 } \\
\cline { 3 - 6 } & inda & \multicolumn{2}{c}{ Pert. } & \multicolumn{3}{c}{ Pert. } \\
\cline { 3 - 6 } & kan & 1 & 2 & 1 & 2 \\
\hline Nilai & 58 & 58 & 67 & 67 & 75 \\
Nilai & 83 & 92 & 92 & 100 & 100 \\
Jumlah siswa & 19 & 10 & 4 & 2 & 0 \\
Jumlah siswa & 15 & 24 & 30 & 32 & 0 \\
\hline Persentase & $\mathbf{1 4}$ & $\mathbf{7 0}$ & $\mathbf{8 8}$ & $\mathbf{9 4}$ & $\mathbf{1 0 0}$ \\
\hline
\end{tabular}

Berdasarkan table di atas dapat dijelaskan bahwa siswa yang mendapat
7

ilai terendah pada pratindakan yaitu engan nilai terendah 58, pada siklus pertama pertemuan I masih tetap sebesar 58, nilai tersebut masih dibawah nilai KKM. Selanjutnya mengalarni kenaikan pada siklus pertama di pertemuan 2 yakni sebesar 67. Kenaikan terjadi kembali pada siklus ke dua pertemuan 2 yakni sebesar 75. Nilai terendah tersebut msudah diatas nilai KKM.

Nilai tertinggi pada pratindakan hanya sebesar 83, pada siklus pertama pertemuan pertama mengalarni peningkatan yakni sebesar 92. Peningkatan nilai tertinggi pada siklus pertama pertemuan 1 ini tetap tidak mengalarni peningkatan pada siklus pertama pertemuan 2. Peningkatan terjadi pada siklus kedua baik pertemuan 1 mau pun pertemuan 2 yang masing-masing 
sebesar 100. Sedangkan untuk presentase dan jumlah siswa tuntas serta tidak tuntas mengalami peningkatandari tindakan ke tindakan berikutnya. Hal ini menunjukkan bahwa media kartu huruf mampu meningkatkan kemampuan membaca siswa.

Berdasarkan hasil penelitian menunjukkan bahwa pada akhir siklus ke dua pertemuan ke 2 diperoleh persentase jumlah siswa yang tuntas sebanyak 100\% atau dengan kata lain tidak ada lagi siswa yang belum tuntas dalam kelas tersebut pada materi membaca, serta nilai individu masing-masing siswa diperoleh lebih dari nilai KKM yang di tapkan maka penelitian dianggap berhasil dan mampu meningkatkan kemampuan siswa dalam hal materi membaca. Dengan demikian maka penelitian dapat dihentikan hanya sampai pada siklus kedua pertemuan 2 . Untuk presentase dan jumlah siswa tuntas serta tidak tuntas mengalami peningkatan dari tindakan ke tindakan berikutnya. Hal ini menunjukkan bahwa media kartu huruf mampu meningkatkan kemampuan membaca siswa.

Berdasarkan hasil penelitian menunjukkan bahwa pada akhir siklus ke dua pertemuan ke 2 diperoleh persentase jumlah siswa yang tuntas sebanyak 100\% atau dengan kata lain tidak ada lagi siswa yang belum tuntas dalam kelas tersebut pada materi membaca, serta nilai individu masing-masing siswa diperoleh lebih dari nilai KKM yang ditetapkan maka penelitian dianggap berhasil dan mampu meningkatkan kemampuan siswa dalam hal materi membaca. Dengan demikian maka penelitian dapat dihentikan hanya sampai pada siklus kedua pertemuan 2 .

\section{KESIMPULAN}

Berdasarkan hasil penelitian tindakan kelas yang telah dilakukan dalam dua siklus melalui penggunaan media kartu huruf pada siswa kelas 2 SD Negeri 6 Klablim Kota Sorong dalam pelajaran bahasa Indonesia tentang pembelajaran membaca lancar dapat diambil kesimpulan sebagai berikut:

Melalui penggunaaan media kartu huruf dapat meningkatkan ketrampilan membaca siswa yang dapat dililiat dengan adanya peningkatan pada prosentase siswa yang tuntas yakni pratindakan sebesar $56 \%$ siklus pertama pertemuan 1 sebesar $70 \%$ naik pada siklus pertama pertemuan 2 sebesar $88 \%$, siklus kedua pertemuan 1 sebesar $100 \%$ dan siklus ke dua pertemuan 2 sebesar $100 \%$.

Melalui penggunaan media kartu huruf dapat meningkatkan keaktifan dan kekreatifan siswa pada scat pelaksanaan pembelajaran bahasa Indonesia, khususnya dalam pembelajaran membaca.

\section{DAFTAR RUJUKAN}

.(2016) Meningkatkan Minat Baca Untuk Anak Papua Barat Lebih Cerdas Dan Sehat, http://www.gotongroyong.fund/ (diakses April 2016) ...(2016) Dari 76 Negara, Minat Baca Siswa Indonesia Peringkat Ke69, harian jogja.com, (diakses April 2016)

Ardiani M. (2007) Mengenal Media Pembelajaran.Situs Pendidikan Indonesia : Edu-articles.com

Arief S. S. Media Pendidikan.Jakarta : PT Raja Grafindo Persada

Bahasa dan Sartra Indonesia di Universitas Sarjana Wiyata Taman Siswa.

Depdikbut. (2001). Petunjuk Praktis

Berbahasa Indonesia. Jakarta:

Pusat Pembinaan dan

Pengembangan Bahasa.

Eko S. (2015). Sukses Ujian Skripsi. Yogyakarta: Cakrawala.

Gorys K. (2008) Komposisi. Flores-NTTIndonesia: Nusa Indah.

Hafni (1981). Pemilihan dan Pengembangan Bahasa Pengajaran Membaca. Jakarta: P3G Depdikbut. 
Harsja W. B (2006) Media Pendidikan. Jakarta: PT Raja Grafindo Persada.

Henry G T. (2016). Membaca Sebagai Suatu Ketrampilan Berbahasa.Bandung: PT Angkasa.

Nuttal. C. (2000) Teaching Reading Skills in a Foreign Language. Macmillan Heinemann Publisher.

Pranowo. (2015). Pengajaran Minat Baca. Yogyakarta: Makalah Temu Ilmiah

Slamet. St. Y. dan Suwarto. (2007). Dasardasar Metodologi Penelitian Kualitatif. Surakarta : UNS Press.

Spargo. (1989) Timet Reading. Providence: Jamestown Publisher.

Suroso. (2007) Penelitian Tindakan Kelas. Pararaton.

Zuchdi, D. (1994) Metodologi Penelitian Kualitatif. Yogyakarta : Lembaga Penelitian UNY. 